IKONOMIKA :Journal of Islamic Economics and Business

Volume 2, No I (20I7)

ISSN: 2527-3434 (PRINT) - ISSN: 2527-5I43 (ONLINE)

Page : I - I8

\title{
Factors Influencing Customer's Acceptance of Islamic Banking Products and Services
}

\author{
MalisahLatip, M.H. Yahya ${ }^{\mathrm{I}}$, Muhammad Junaina ${ }^{2}$ \\ Universiti Putra Malaysia $^{3}$ \\ malisah@upm.edu.my ${ }^{1}$, mohdhisham@upm.edu.my ${ }^{2}$,junaina@upm.edu.my ${ }^{3}$
}

\begin{abstract}
The emergence of Islamic banking system has had a huge impact on the financial industry. This research attempts to identify the influential factors that are associated with Islamic banking adoption between the Muslim and non-Muslim populations in Sarawak, Malaysia. With the "adoption of Islamic banking" as the dependent variable, this study studies its relationship with seven independent variables. They are, four attributes of innovation, namely; I) relative advantage, 2) compatibility, 3) observability and 4) complexity, and three additional variables namely; 5) perceived risk, 6) perceived trust and 7) customer innovativeness. A convenient sampling method is used whereby a questionnaire is administered to 436 respondents in Sarawak, Malaysia. Using the logistic regression method, three factors; I) compatibility, 2) relative advantage/observability and 3) complexity are found to have significant relationship with customers' adoption of Islamic banking products and services.
\end{abstract}

Keywords: Islamic Banking, Adoption, Diffusion Of Innovation Theory, Logistic Regression

\begin{abstract}
Abstrak
Perkembangan pada sistem perbankan syariah membawa dampak yang sangat besar terhadap industri keuangan. Kajian ini bertujuan untuk mengidentifikasi faktorfaktor memengaruhi penerimaan bank syariah antara masyarakat muslim dan nonmuslim di Sarawak, Malaysia. Variabel dependen yang dipergunakan dalam penelitian ini ialah penerimaan terhadap bank syariah. Terdapat empat attribut inovasi yaitu: I) keuntungan relatif, 2) kesesuaian, 3) pengamatan, 4) kompleksitas. Serta tiga variabel tambahan, yaitu: 5) risiko yang diharapkan, 6) kepercayaan yang diharapkan, 7) inovasi dari nasabah. Metode pengambilan sampel dengan teknik convenient mendapatkan 436 responden di Sarawak, Malaysia. Teknik analisis yang dipergunakan ialah regresi logistik dengan tiga faktor: I) kesesuaian, 2) keuntungan relatif/pengamatan, dan 3) kompleksitas ditemukan memiliki pengaruh yang signifikan terhadap penerimaan nasabah atas produk dan jasa bank syariah.
\end{abstract}

Kata Kunci: Bank Syariah, Penerimaan, TeoriDifusiInovasi, RegresiLogistik

Received: February I0, 20I7- Revised: April 25, 20I7- Accepted : May 8, 2017 Universiti Putra Malaysia

E-mail: malisah@upm.edu.my,mohdhisham@upm.edu.my,junaina@upm.edu.my

DOI: I0.24042/febi.v2iI.943 


\section{A. INTRODUCTION}

Islamic banking system has been introduced in Malaysia since the mid1980s. It has transformed from being a niche banking systemoffering Islamic compliant financialproducts, to an important sector in the Malaysian financial industry. The introduction of Islamic banking system has been motivated by the demands and needs of Muslim clients who are looking for alternatives in obtaining financing and investment products which comply with their religious beliefs. In the early years, Islamic banking products and services were not as competitive compared to ones offered by the already established conventional system, especially in the aspects of pricing and service offerings. However, findings by Yahyaet al., (20I2) prove that banks that are involved in Islamic banking are able to compete and be at par with their conventional counterparts. In spite of the fact that Islamic banks are restricted by Islamic principles in its operations, they are able to maintain a performance that is equivalent to that of conventional banks'.

In general, an Islamic bank can be defined as an interest-free based financial institution, which operates in accordance with Islamic laws (Abdul-Qawi and Owen, 200I). Islamic banking emphasizes on the wellbeing of public (maslahah), whereas, conventional banking emphasizes on individual's utility (Al-Qaradhawi, 2009). According to Gait and Worthington (2007), Islamic banking prohibits five major elements, I) riba, 2) gharar, 3) maisit, 4) non-halal products, and 5) sinful and social irresponsible activities. The prohibition of haram, immoral and negative elements from economic activities, provides a strong foundation for business to grow regardless of the fluctuations of macroeconomic variables(Yahyaet al., 2013).

In the Malaysian context, although there exists a growing awareness and understanding of the concept of Islamic banking operations among Muslims, as well as non-Muslims, this has not been reflected interms of sales of lslamicbanking products. Even though public's knowledge on Islamic banking system has increased considerably since the establishment of the first Islamic bank (Bank Islam Malaysia Bhd, BIMB) three decades ago, customers' attitudes towards the adoption of Islamic banking products have yet to rise at a similar pace. This is witnessed by the low usage of Islamic banking products and services compared to conventional banking's among Malaysians (Raman, 2010; Doraisamyet al., 20II; Thambiahet al., 20I2).

The main objective of this study is to look at the factorsinfluencing the acceptance of Islamic banking products and services. According to Haronand Nursoviza. (2005), even though Islamic financial institutions assert that their 
marketing programs are comprehensive (in promoting Islamic banking products and services), their outcomes are far from satisfactorygiven the marketing efforts put in. This supported by Ahmad and Haron (2002) discover that Islamic banks have not done enough in marketing their products to the corporate sector. Aziz (2007), states the Islamic banking operations in Malaysia have not completely diffused or reached into the entire levels of the society compared to its mature conventional banking counterparts. Although there are increasing statistics of Malaysian banking clients utilizing Islamic banking products and services, most of them have not adopted the system in total.

This study attempts to identify the factors that influence customer's adoption of Islamic banking products and services offered by banks in Sarawak. Rogers's Diffusion of Innovation model is used to explain the reason behind the motivation of customers in their decision whether to adopt or not to adopt Islamic banking products and services(withIslamic banking as a new innovation in the banking industry services that needs to be diffused in the society).In short, the research question of this study is, "What are the factors that significantly influence the adoption of Islamic banking products and services?" According to Rogers (197I), diffusion is the process through which innovations are spread to the members of a social system. Generally, there are four main components in the diffusion of innovation, which includes I) innovation, 2) communication channels, $3)$ time and 4) the social system.

Rogers (2003) asserts that the diffusion of an innovation among a particular population can be characteristically measured by its implementation rate. Academic studies in the field of diffusion and adoption have been inspired by the scholarly work of Rogers (2003). Rogers' Diffusion of Innovation (DOI) theory is one of the most commonly used models in the field of adoption behavior prediction in social science. According to Hussein et al. (20II), Roger's perceived attributes-of-innovation model is the preeminent theoretical model related to customer-based studies.According to the model, the decision to adopt may be influenced by various factors, such as, I) relative advantage, 2) compatibility, 3) observability, 4) complexity, 5) perceived risk, 6) perceived trust and 7) customer innovativeness.

\section{B. LITERATURE REVIEW}

The traditional definition of the term "adoption", which is, "making full use of new ideas as the best course of action available", originates from Rogers and Shoemaker (197I). Consumers are assumed to have undergone "a process of knowledge, persuasion, decision and confirmation" before they are ready to adopt a 
product or service. Sathye (1999) describes adoption as "the acceptance and continued use of a product, service or idea". Rogers (2003) visualizes the innovation-decision process as "the mental process by which an individual goes by from first knowledge of an innovation to a decision whether to adopt or reject and to the confirmation of this decision".

There have been numerous studies that focus on customer's adoption of innovative banking products such as mobile banking, Internet banking and Automated Teller Machines (ATM). Table I, shows the four areas of studies with regard to innovations in banking that have been conducted by researchers using Rogers's Diffusion of Innovation theory(by adopting the attributes of innovation as independent variables).

\section{Table I}

Studies in Banking using DOI Theory

\begin{tabular}{|c|c|c|c|}
\hline $\begin{array}{c}\text { Type of } \\
\text { Product } \\
\text { Innovation }\end{array}$ & Year & Author/Researcher & Theory \\
\hline Automated & 1994 & Rugimbana and Iverson & \multirow{13}{*}{$\begin{array}{c}\text { Diffusion of } \\
\text { Innovation } \\
\text { (DOI) } \\
\text { Theory, } \\
\text { Rogers }\end{array}$} \\
\hline Teller Machine & 2009 & Olatokun and Igbinedion & \\
\hline Cell & 2003 & Brown et al. & \\
\hline Phone/Mobile & 2012 & Al-Jabri and Sohail & \\
\hline Banking & 2013 & Mian and Rizwan & \\
\hline & 2000 & Tan andTeo & \\
\hline Internet & 2003 & Gerard and Cunningham & \\
\hline Banking & 2004 & $\begin{array}{c}\text { Kolodinsky, } \mathrm{Fogarth} \text { and } \\
\text { Hilgert }\end{array}$ & \\
\hline \multirow{5}{*}{ Islamic Banking } & 2012 & Rambocas and Arjoon & \\
\hline & I999 & Yusof, M.Y.R & \\
\hline & 2010 & Raman, R. & \\
\hline & 2012 & $\begin{array}{l}\text { Thambiah, Ramanathan and } \\
\text { Mazumder }\end{array}$ & \\
\hline & 2014 & $\begin{array}{l}\text { Jamshidi, Hussin, Hashemi, } \\
\text { Hosseini and Rostami }\end{array}$ & \\
\hline
\end{tabular}

Source: Adopted from Raman (2010)

Rugimbana and Iverson (1994) carry out a study on the usage of ATM by banking customers in Australia. They surveysamples of customers from two banks and conclude that the bank marketers'capability to increase the usage of ATM is highly dependent on the strategy to focus on the relative advantage attributes of the 
ATM. The respondents who perceived ATMs to be convenient, reliable, and, generally, risk free,are more willing to use them. Using the cluster sampling method, Olatokun and Igbinedion (2009) employ the principal factor analysis and multiple regression to analyze 428 questionnaires respondents in Nigeria. Their study reveals that the constructs of relative advantage, complexity, compatibility, observability and trialability have significant impact on the attitude of bank's consumer toward the usage of ATM, which in turn, have a significant influence on the intention to use it.

Findings by Brown et al. (2003) depict that relative advantage and trialability have significant impact on the attitudes of customers in adopting cell phone banking in South Africa.This signifies the customers'requirement for cell phone banking services to be (or perceived to be) of lower risk before it is being adopted. However, factors such as compatibility, complexity and self-efficacy do not exhibit any influence on cell phone banking adoption. Findings by Al-Jabri and Sohail (2012), suggest that 'compatibility' is found to be the most significant factor to predict mobile banking adoption, followed by 'relative advantage' and 'observability'. All these factors show positive impact on the adoption of mobile banking in Saudi Arabia. However, 'perceived risk' is found to have a negative relationship with the adoption of mobile banking. This implies that customers observe risk as the main barrier to the adoption of new innovation. Nonetheless, this study finds that 'complexity' and 'trialability' are perceived to be negligible in the decision whether to adopt or not mobile banking services in Saudi Arabia. Mian and Rizwan (2013) combine two conceptual perspectives to investigate the main factors that affect the adoption of mobile banking in Pakistan. They reveal that 'perceived compatibility', 'perceived ease of use' and 'perceived relative advantage' have significant positive impacts on the attitude towards mobile banking adoption.

Research done by Gerard and Cunningham (2003) identifies eight characteristics that affect the rate of adoption. Results from this study indicate that adopters of internet banking perceive the service to be less complex, more convenient, more suited to those who are computer proficient. Apart from that, Kolodinskyet al. (2004) applies the theory of Technology Acceptance Model (TAM) and DOI theory to explore the predictors that affect the intention of US consumers to adopt internet banking. Their study finds that 'relative advantage' and 'compatibility' have significant and positive influence on e-banking products adoption. Rambocas and Arjoon (2012) use the DOI theory and SEM analysis and conclude that 'perceived relative advantage' and, to a lesser extent,'government 
support' as the two primary factors of internet banking loyalty among I37 students in Trinidad and Tobago.

In the Islamic banking context,Yusof (1999) applies the Rogers diffusion model (2003) in the study on the introduction of Islamic banking to the Muslim community in Singapore. The data is collected from two different sources, I) Association of Muslim Professional (AMP) and 2) mosques. Six perceived characteristics of innovations (PCI), namely I) relative advantage, 2) social desirability, 3) complexity, 4) compatibility, 5) result demonstrability and 6) perceived risk are employed as the independent variables. The study finds that three factors; compatibility, complexity and result demonstrability serve as the main reasons for customers' intention to adopt Islamic banking in Singapore. Raman (2010) utilizes this theoretical framework in the context of Malaysia. His study employs four PCIs namely I) economic advantage, 2) compatibility, 3) social desirability, and 4) complexity as independent variables. The result of logistic regression finds that only 'economic advantage' significantly influences Islamic banking adoption in the northern part of Peninsular Malaysia. Thambiahet al. (2012) expand the scope of the study to cover several states in Peninsular Malaysia including Kuala Lumpur, Selangor, Johor, Ipoh, Kelantan, Terengganu and Negeri Sembilan. In addition to PCIs, this study incorporates three additional variables to determine the factors that influence the usage of Islamic retail banking (IRB). They are;I) awareness on IRB attributes, 2) promotional efforts and 3) perceived information quality. The results of multiple linear regression imply that 'relative advantage', 'compatibility', 'promotional efforts', 'complexity' and 'consumer awareness' have significant relationships with the usage of Islamic retail banking (IRB) products.

\section{Development of Hypotheses}

Relative advantage is the extent to which an innovation is better than the one it replaces. The feature of innovation that contributes to relative advantage includes 'economic and social advantages' (Rogers, 2003). Diffusion researchers have acknowledged relative advantage as one of the greatest predictors of an innovation's rate of adoption. Relative advantage specifies the benefits and the costs ensuing from the adoption of an innovation. Moreover, the 'degree of economic profitability', 'social prestige', 'low initial cost', 'the immediacy of the reward', 'a decline in discomfort', and 'a savings in effort and time'have been depicted as the sub-divisions of relative advantage (Gerard and Cunningham 2003). This study intends to explore the economic benefits (i.e.service charges, profits 
earnings and incentives) of Islamic banking products and services, vis-a-vis the framework of relative advantage. Below is the first hypothesis for this study.

\section{$H_{I}$ : Relative advantage positively influences Islamic banking adoption Compatibility}

Rogers (2003) expresses 'compatibility' as the degree to which an innovation is perceived as consistent with the I) existing values, 2) past experiences and 3) needs of potential adopters. Compatibility assures better security and fewer risks and generates new notionthat is more meaningful to the receiver. An innovation is possibly compatible with (i) socio-cultural values and beliefs, (ii) formerly introduced ideas, or (iii) client needs for innovations.Compatibility in Islamic banking adoption is depicted as the configuration of customers banking preference with customer's existing habit, need and style.

Previous research in Islamic banking that tested the influence of compatibility very scarce and limited. For example, Amin et al. (2013), explore the effects of relative advantage, compatibility, perceived behavioral control, subjective norm and simplicity on the adoption of Islamic home financing in Malaysia. Their results show that attitude does not mediate the relationship between compatibility and the Islamic home financing adoption. Another study by Raman (2010) indicates that construct compatibility appear to be insignificant in influencing the decision to adopt or not the Islamic banking products. The second hypothesis of this study is as below:

\section{$H_{2:}$ Compatibility positively influences Islamic banking adoption Observability}

Rogers (2003) defines observability as 'the degree to which the results of an innovation are visible to the members of a social system and its benefits can be simply observed and communicated'. Certain ideas are effortlessly observed and communicated to others, while some different ideas or innovations are hard to observe or explain. According toYusof (1999), the existence of these differences in term of the way the innovation can be observed, is due to the characteristic of a service which is intangible that might hinder its visibility.

In this research, observability is studied from the perspective of customers' I) observing the benefits and outcome of practicing Islamic banking products and services (in view of the opinion of family, friends and peers in relation to Islamic banking) and 2) readiness to tell others their experience when using of Islamic banking products and services. If existing customers find it easy to communicate the benefits of the product, the benefits will be more visible and receive better acceptance from other potential adopters. The third hypothesis for this study is as below: 


\section{$H_{3:}$ Observability positively influences Islamic banking adoption Complexity}

Cheung et al. (2000) define 'complexity' as the degree to which an innovation is perceived as relatively hard to understand and use. Rogers (2003) states that not everyinnovation is readilyunderstood by members of the social system. In comparison, new innovations that areeasy to understand or uncomplicated are adopted more quickly than those that requirethe adopter to build up new skills and understandings. Even though Islamic banking services can be considered as a new concept, it is still a form of continuous financial innovation. Customers are not required to create many changes in their usage pattern of banking services. Individuals will likely adopt Islamic banking when they discover such products and services are easy to understand and simplify their banking needs. Previous study by Yusof (I999) and Gerardand Cunningham (2003) have affirmed that a negative relationship exist between complexity and adoption rate. The fourth hypothesis for this study is as below;

\section{$H_{4}$ : Complexity negatively influences Islamic banking adoption Perceived Risk}

The concept of perceived risk has been introduced since 1960 to interpret user behavior and factors influencing their decision-making (Taylor, 1974). These attributesrefer to the degree of risks in using an innovation (Ram andSheth, 1989).In the perspective of Islamic banking, perceived risk is portrayed as the probability that a product does not perform as expected (Yusof, 1999). In Malaysia, the operations of Islamic bank is strictly governed and monitored by the Central Bank of Malaysia (Bank Negara Malaysia - BNM) and regulated under Islamic Financial Services Act (IFSA) 2013. These risk controlling factors may lead to acceptance among Muslims consumers since all the products and services offered by Islamic bank are perceived as truly adherent to the Shariahlaw. However,there exist mistrust and uneasiness, especially, in the case of conventional banks, which set up Islamic window to sell Islamic financial products. This is due to the fact that these banks handle both interest-free banking and interest banking operations at the same time. Muslim consumers are concern with the level of Shariah observance of their products. Hypothesis five is as below:

\section{Hs: Perceived risk negatively influences Islamic banking adoption}

Perceived Trust

The concept of trust is relatively essential in the field of marketing. It is a main moderator of customer-oriented marketing (Kantspergerand Kunz, 2010). According to Muawanah (2010), due to the absence of universal definition,trust has 
become an abstract concept. It is frequently used together with reliability, credibility or confidence. Trust is a multi-faceted concept, which unites the elements of emotional, cognitive and behavior. Mayer et al. (1995) describe trust as a willingness to be in a vulnerable situationwith a positive expectation towards other party's future behavior. They also agree that the trust is the possibility of someone accepting cooperation behavior from other parties. This study investigates the impact of perceived trust towards Islamic banking adoption.If customers havetrust in Islamic banking operations, its products and services will be perceived as respectable and will not lead to any adverse outcomes. Generally, individuals will have greater intention to adopt Islamic banking products when they believe that its operation is secure and trustworthy. Below is the sixth hypothesis for this study.

\section{H6: Perceived Trust positively influences Islamic banking adoption.}

\section{Customer Innovativeness}

The concept of innovativeness has obtained wide-rangingdeliberation among the diffusion of innovation framework (Rogers, 2003). It has received meticulous attention in innovation study generally, and marketing research particularly(Midgley and Dowling, 1978; Flynn and Goldsmith, I993). In relation to this exclusive framework, personal innovativenessdefined as the degree and speed of adoption of an innovation by an individual. In the context of marketing, this construct has been evaluated through the I) 'purchase intentionsviewpoint' for some new products, 2) 'quantity of new products owned', as well as 3) 'relative time of adoption' for specific new products. These are typically used in domainspecific products and services (Lassaret al., 2005).

Manning et al. (I995) describe that customers who display high level of innovative characteristic have I) a propensity to make decisions to adopt innovations independently, 2) a great interest in novelty and 3) a strong willpower to discover new product information. Hoffman and Soyez (2010) indicate that innovative customers employ distinctive medium to search information and regularly concentrate on particular categories of product. They are more probably to be opinion leaders and early adopters of new products. This construct is included in this study because it is expected to influence customers in adopting Islamic banking products and services. Below is the seventh hypothesis of this study.

\section{H7: Customer Innovativeness positively influences the adoption of Islamic banking. C. METHOD}


For the purpose of this study, the region of Bintulu, Sarawak, is selected as the study area. Sarawak is one of the two Malaysian states in the island of Borneo. It is situated on the northwest of the island, bordering the state of Sabah to the north. The selection of this location is because Bintulu is one of the rapidly developing cities in Sarawak. Bintulu, which is also known as 'Energy Town' of Sarawak, is the fourth largest city in Sarawak. The data collection method employed in this study is a survey using structured questionnaire through convenient sampling. Data are collected via a self-administrated questionnaire. A total of 500 questionnaires were distributed to the targeted locations, and 477 questionnaires were returned. 4I incomplete questionnaires were excluded from the analysis. The instruments used for this study (which is structured questionnaire) is based on three previous research papers and are modified to suit the current research content (Yusof, I999; Raman, 2010 and Moore andBenbasat, I99I)

The framework shown in Figure I provides the conceptual foundation of this present research.

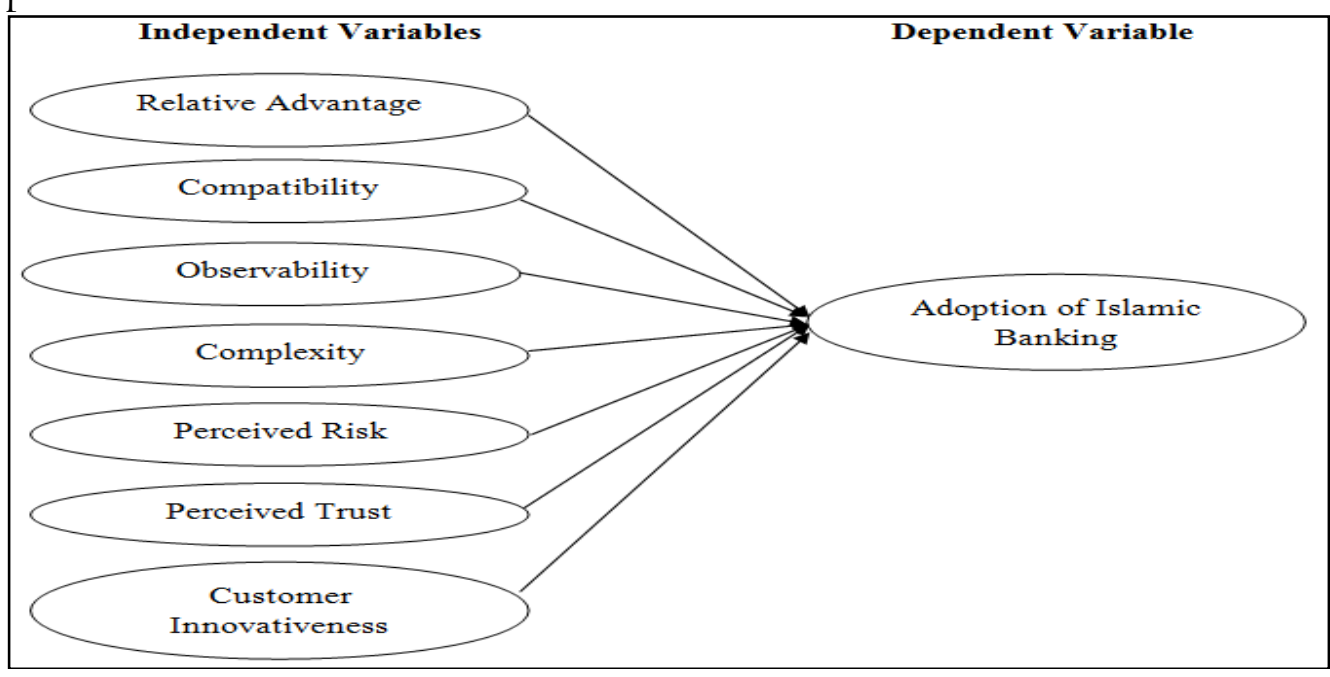

Figure I

\section{Research Framework}

Factor analysis and binary logistic regression are used to analyze the data obtained. Reliability and validity test of the data are also carried out to ensure internal consistency based on Cronbach's alpha.

\section{RESULT AND DISCUSSION}

\section{Factor Analysis}

The exploratory factor analysis (EFA) is conducted in this study to achieve the objective of identifying the factors that significantly influence customers' 
adoption of Islamic banking products and services. The Kaiser-Meyer-Olkin $(\mathrm{KMO})$ measure of sampling adequacy is $0.94 \mathrm{I}$, greater that the recommended value of 0.6 as the minimum value for a good factor analysis (Tabachnick and Fidell, 1996). The overall significance of the correlation matrix is 0.000 with the value of Bartlett's test of sphericity at I47I4.027. A value of less than 0.0000 with the Bartlett's test of sphericity indicates that the data could be ideal for factor analysis. The communalities are all above 0.3 , further confirming that each item shares some common variance with other items. Given these overall indicators, factor analysis is deemed to be suitable for all 35 items.

Principal Component Analysis (PCA) is used to identify and compute composite scores for the factors attributes of innovation. Initial eigenvalues indicate that the first six factors explain $49.12 \%$, II.23\%, 7.38\%, 4.53\%, 3.95\% and $3.45 \%$ of the variance respectively. Solutions for all these six factors are examined using the Varimax rotation of the factor-loading matrix. Furthermore, using scree test criterion, six factors are suggested for retention. All expected factors emerged fairly "cleanly" except for factors, namely 'relative advantage' and 'observability'. Some items in these constructs are loaded as one factor. Items, which are crossloaded, are removed and only items with factor loadings greater than 0.5 are included in the analysis. As a result, a total of five items are excluded from the analysis. The results from factor analysis find that two constructs ('Relative Advantage' and 'Observability') fail to load as separate factors. They are thus combined as a single variable 'Relative Advantage/Observability'.

Table 2 presents the six-factored solution, together with factor loadings for each item, the percentage of variance explained and internal reliability which is measured by Cronbach's alpha. The six interpretable factors explain 47.33 percent, I3.0I percent, 7.65 percent, 4.88 percent, $4.5 \mathrm{I}$ percent and 3.88 percent of the variance respectively. Overall, these factors explain 8I.25 percent of the total variance, which is satisfactory as it is higher than common consideration percentage of variance explained at 60.0 percent or less in the social science disciplines (Hair et al., 2010).Cronbach's alpha. The Cronbach's $\alpha$ coefficient for the six factors, range from 0.907 to 0.963 , indicating good internal reliability.

Table 2

Rotated Component Matrix for Six Dimensions

\begin{tabular}{ccc}
\hline Item/Factor & Variance & Cronbach's $\boldsymbol{\alpha}$ \\
\hline Factor I: Customer Innovativeness & $47.33 \%$ & 0.943 \\
\hline
\end{tabular}




\begin{tabular}{lcc}
\hline Factor 2: Compatibility & $13.02 \%$ & 0.963 \\
Factor 3: Relative Advantage and & $7.65 \%$ & 0.931 \\
Observability & & \\
Factor 4: Complexity & $4.88 \%$ & 0.952 \\
Factor 5: Perceived Risk & $4.51 \%$ & 0.907 \\
Factor 6: Perceived Trust & $3.88 \%$ & 0.928 \\
\hline
\end{tabular}

On the basis of the analysis, the 35 items are grouped into six factors, namely 'customer innovativeness', 'compatibility', 'relative advantage/observability', 'complexity', 'perceived risk', and 'perceived trust'. The six-factored scale is further checked individually to scrutinize overall internal consistency of each factor using Cronbach's alpha. The Cronbach's $\alpha$ coefficient for the six factors ranged from 0.907 to 0.963 , signifying a good internal reliability.

The binary logistic regression analysis is then performed to identify influential factors which are associated with 'Islamic banking adoption' as the dependent variable. Backward elimination, a method of stepwise binary regression is used in the analysis because it willretain only the predictor variables that are statistically significant in the model (Menard, 2002). The regression results are shownin Table 3.

From table 3, the coefficient for 'Compatibility' is 0.704 , this implies that $\operatorname{Exp}(\beta)=\operatorname{Exp}(0.704) \approx 2.02 \mathrm{I}$. A unit increase in 'Compatibility', ceteris paribus, will lead to the respondents to be 2.02I more times likely to adopt Islamic banking products and services. Thus, a high value of 'Compatibility' is associated with an increase in Islamic banking adoption. The coefficient of 'Relative Advantage/Observability' is 0.518 , this implies that $\operatorname{Exp}(\beta)=\operatorname{Exp}(0.518) \approx$ I.679. A unit increase in the factor 'Relative Advantage/Observability', holding other variables constant, will lead to an increase of 1.679 times in the odds of respondents to adopt Islamic banking. Thus, a high value of 'Relative Advantage/Observability' is associated with an increase in Islamic banking adoption.

The coefficient of Complexity is -0.794 , this implies that $\operatorname{Exp}(\beta)=\operatorname{Exp}(-$ $0.794) \approx 0.452$. Thus, a unit increases in 'Complexity', will cause the odds of respondents to adopt Islamic banking to decrease by a factor of 0.452 , ceteris paribus. Thus, only 'Compatibility', 'Relative Advantage/Observability', and 'Complexity' are significant in predicting the odds of an increase (or decrease) in Islamic banking adoption.

Table 3

Logistic Regression

$\begin{array}{lllllll}\text { Factors } & \text { B } & \text { S.E. Wald df Sig. } & \operatorname{Exp}(B) & \begin{array}{c}95 \% \text { C.I. for } \\ \operatorname{EXP}(B)\end{array}\end{array}$


Lower Upper

\begin{tabular}{|c|c|c|c|c|c|c|c|c|}
\hline $\begin{array}{l}\text { Customer } \\
\text { Innovativeness }\end{array}$ & .036 &. $\mathrm{I} 39$ & .067 & I & .796 & I.036 & .790 & $\begin{array}{r}1.36 \\
0\end{array}$ \\
\hline Compatibility & .704 & .115 & $\begin{array}{r}37.40 \\
8\end{array}$ & I & $.000^{* *}$ & $2.02 \mathrm{I}$ & $\begin{array}{r}\text { I.6I } \\
3\end{array}$ & $\begin{array}{r}2.53 \\
2\end{array}$ \\
\hline $\begin{array}{l}\text { Relative } \\
\text { Advantage / } \\
\text { Observability }\end{array}$ & .518 & .172 & 9.119 & I & $.003^{* x}$ & I.679 & $\begin{array}{r}1.19 \\
9\end{array}$ & $\begin{array}{r}2.34 \\
9\end{array}$ \\
\hline Complexity & .794 &. $\mathrm{I} 4 \mathrm{I}$ & $\begin{array}{r}37.40 \\
8\end{array}$ & I & $.000^{* *}$ & .452 & .343 & .596 \\
\hline Perceived Risk & $\begin{array}{r}- \\
.018\end{array}$ & .135 & .018 & I & .892 & .982 & .753 & $\begin{array}{r}\mathrm{I} .28 \\
0\end{array}$ \\
\hline Perceived Trust & .066 & .236 & .078 & I & .780 & $\mathrm{I} .068$ & .673 & $\begin{array}{r}1.69 \\
6\end{array}$ \\
\hline Constant & $\begin{array}{r}2.08 \\
3 \\
\end{array}$ & $\begin{array}{r}1.08 \\
5 \\
\end{array}$ & 3.688 & I & .055 & .125 & & \\
\hline
\end{tabular}

Compatibility turns out to be the most important factor in the Islamic banking adoption. Majority of the adopters of Islamic banking products and services observe Islamic banking as well suited to their existing habits, needs and style. This is an expected finding as almost half of the respondents (46.8 percent) are Muslims and strictly adhere to the Islamic teachings.

Relative Advantage and Observabilityis the second significant factor in the decision to adopt Islamic banking products and services. These two factors explain the degree to which the benefits of using Islamic banking products and services can be observed and communicated with the other members in the social system. The benefits here can be described in the dimensions of economic profitability, social prestige, low initial cost, the immediacy of the reward, a decline in discomfort, and a saving in effort and time which have been depicted as sub-divisions of relative advantage. The results from factor analysis find that these two constructs fail to load as separate factors.

'Complexity is the third significant factor in influencing the decision to adopt Islamic banking among customers. According to Rogers (2003), certain innovations readily understood by members of social systems. Therefore, even though Islamic banking services can be considered as a new concept, it is still a form of continuous financial innovation, which suggests that customers are not required to create many changes in their usage pattern of banking services. The findings of this study reveal that 'Complexity' is negatively associated with the 
Islamic banking adoption. This illustrates that individuals are not likely to adopt Islamic banking if they discover that such products and services are complicated and difficult to understand.

There are three factors found to be statistically not significant in the respondents' decision to adopt Islamic banking. They are, 'Perceived Risk', 'Perceived Trust', and 'Customer Innovativeness'. The result shows that the 'Perceived Risk' does not have a direct relationship with the decision of customers to adopt Islamic banking. As one of the prominent players in the field of financial system, Islamic banking in Malaysia is closely governed by the Central Bank of Malaysia (BNM). This demonstrated by the establishment of Shariah Supervisory Council to monitor the operations of Islamic banking. This explains why customers observe 'Perceived Risk' as unimportant in their decision to adopt Islamic banking as the central Bank's supervision would reduce its risks..

Table 4

Hypotheses Results on Relationship between Independent Variables and Islamic Banking Adoption

\begin{tabular}{|c|c|c|c|c|}
\hline & Hypotheses & Wald & Sig. & Results \\
\hline $\mathrm{H}_{\mathrm{I}}$ & $\begin{array}{l}\text { Relative Advantage/Observability } \\
\text { positively influences Islamic Banking } \\
\text { Adoption. }\end{array}$ & 9.119 & .003 & Sup \\
\hline $\mathrm{H}_{2}$ & $\begin{array}{l}\text { Compatibility positivelyinfluences Islamic } \\
\text { Banking Adoption. }\end{array}$ & 37.408 & .000 & Supported \\
\hline $\mathrm{H}_{3}$ & $\begin{array}{l}\text { legatively influences Islamic } \\
\text { ption. }\end{array}$ & 37.408 & .000 & Supported \\
\hline $\mathrm{H}_{4}$ & $\begin{array}{l}\text { k negativelyinfluences Islamic } \\
\text { ption. }\end{array}$ & .018 & .892 & $\begin{array}{c}\text { Not } \\
\text { Supported }\end{array}$ \\
\hline $\mathrm{H}_{5}$ & $\begin{array}{l}\text { Perceived Trust positiv } \\
\text { Islamic Banking Adopt }\end{array}$ & .078 & .780 & $\begin{array}{c}\text { Not } \\
\text { Supported }\end{array}$ \\
\hline $\mathrm{H}_{6}$ & $\begin{array}{l}\text { Customer Innovativenes } \\
\text { positivelyinfluences Islamic Banking } \\
\text { Adoption. }\end{array}$ & .067 & .796 & $\begin{array}{c}\text { Not } \\
\text { Supported }\end{array}$ \\
\hline
\end{tabular}

A similar explanation can be applied to the reason why 'Perceived Trust' is found to be a non-significant factor in determining the decision to adopt Islamic banking. It is worth mentioning that the main dimensions measuring 'Perceived Trust' in this study is the perception of customers on the security and trustworthiness of Islamic institutions, how the banks deal with clients and 
compliance with the Shariah principles. These dimensions are not seriously considered by the customers in Bintulu while selecting the type of Islamic banking products to adopt.

Another factor that emerges to be not significant as a determinant on the decision to adopt Islamic banking is 'Customer Innovativeness'. As described by Manning et al. (I995), customers who display a high level of innovative characteristic have a propensity to make decisions to adopt innovations independently. The result of this study indicates that the customers in Bintulu do not consider the attribute of 'Customer Innovativeness' as important in their decision to adopt (or not) Islamic banking facilities. This finding points out that, customers are not concerned with the level of personal innovativeness that they possess. What is important to them is how well the new innovation (Islamic banking products and services) benefits them. Table 4 summarizes the findings of this study.

\section{E. CONCLUSION}

This study investigates the motivations in adopting Islamic banking in Bintulu, Sarawak. It shows that'Compatibility', 'Relative Advantage/Observability' and 'Complexity' have statistically significant relationship with the decision to adopt Islamic banking. Thus, banks need to take these factors into account when developing their Shariahcompliant products and services to ensure the success of their Islamic banking products and services.Banks need to enhance accessibility, profitability and service quality factors.

Islamic banking institutions should not emphasize and depend only on religious aspects to attract new customers. Islamic products need not onlybe perceived as compatible to the religious belief of Muslims customers but must also be perceived as compatible in the perspective of banking needs among the nonMuslims customers. The prospective customers might have a different perception on Islamic banking. For example, some mightviewIslamic banking as a complex and complicated system, even though all the basic procedures are practically and technically similar to conventional systems except for the underlying fundamentals that are based on Shariah principles.

\section{REFERENCES}

Ahmad, N. andHaron, S. (2002). Perceptions of Malaysian Corporate Customers Towards Islamic Banking Products and Services.International Journal of Islamic Financial Services, 3(I): I3-29. 
Abdul-Qawi, O. and Owen, L. (200I). Adopting and Measuring Customer Service Quality (SQ) in Islamic banks: A Case Study in Kuwait Finance House. International Journal of Islamic Financial Services, Vol.3, No.I: I-26.

Al-Jabri, I.M. and Sohail, M.S. (2012). Mobile Banking Adoption: Application of Diffusion of Innovation Theory. Journal of Electronic Commerce Research, Vol. I3(4): 379-39I.

Al-Qaradhawi, Y. (2009).Ekonomi Islam NilaidanAkhlak. Kuala Lumpur: YaPEIM.

Amin, H., Abdul Rahman, A.R. and Abdul Razak, D. (2013). An Integrative Approach for Understanding Islamic Home Financing Adoption in Malaysia.International Journal of Bank Marketing, 3I(7): 544-573.

Aziz, Z.A. (2007). Governor of Central Bank of Malaysia: Keynote address at INCEIF, Inaugural Intellectual Discourse, 23 February, Kuala Lumpur.

Brown, I., Cajee, Z., Davies, D. and Stroebel, S. (2003). Cell Phone Banking: Predictors of Adoption in South Africa: An Exploratory Study. International Journal of Information Management, Vol. 23, No. 5: 38I-94.

Cheung, W., Chang, M.K. and Lai, V.S. (2000). Prediction of internet and World Wide Web usage at work: a test of an extended Triandis model. Decision Support Systems, Vol. 30, No. I: 83-I00.

Doraisamy, B., Shanmugam, A. and Raman, R. (201 I). A study on consumers' preferences of Islamic banking products and services in Sungai Petani.Academic Research International, I(3): 20I-2I0.

Flynn, L.R. and Goldsmith, R.E. (1993). A Validation of The Goldsmith and HofackerInnovativeness Scale.Educational and Psychological Measurement, Vol. 53: IIO5-III6.

Gait, A.H. and Worthington, A.C. (2007). A Primer on Islamic Finance: Definitions, Sources, Principles and Methods. Working Paper Series No. 07/05. University of Wollongong, School of Accounting and Finance.

Gerard, P. and Cunningham, J.B. (2003). The Diffusion of Internet Banking Among Singapore. International Journal of Bank Market, 2I: I6-28.

Hair, J., Anderson, R.E., Tatham, R.L., and Black, W.C. (20I0). Multivariate data analysis. $7^{\text {th }}$ ed. New Jersey: Prentice-Hall Inc.

Haron, S. and Nursofiza, W.A. (2005). Marketing strategy of Islamic banks: a lesson from Malaysia. International Seminar on Enhancing Competitive Advantage on Islamic Financial Institutions.

Hoffmann, S. and Soyez, K. (20I0). A Cognitive Model to Predict DomainSpecific Consumer Innovativeness.Journal of Business Research, 63(7): 778785.

Hussein, R., Mohamed, N., Ahlan, A. R. and Mahmud, M. (20I I). E-government application: an integrated model on G2C adoption of online tax. Transforming Government: People, Process and Policy, 5(3): 225-248. 
Kantsperger, R., and Kunz, W. H. (2010). Consumer trust in service companies: a multiple mediating analysis. Managing Service Quality, 20(I): 4-25.

Kolodinsky, J. M., Hogarth, J. M., and Hilgert, M. A. (2004). The adoption of electronic banking technologies by US consumers. International Journal of Bank Marketing, 22(4/5): 238- 259.

Lassar, W. M., Manolis, C., and Lassar, S. S. (2005). The Relationship BetweenConsumer Innovativeness, Personal Characteristics, and Online Banking Adoption.International Journal of Bank Marketing, 23(2): I76-I99.

Manning, K. C., Bearden, W. O. and Madden, T. J. (I995).Consumer Innovativeness and The Adoption Process.Journal of Consumer Psychology, 4(4): 329-345.

Mayer, R. C., Davis, J., and Schoorman, F. D. (I995).An Integrative Model of Organizational Trust.Academy of Management Review, 20(3): 709-734.

Menard. (2002). Applied logistic regression analysis, $2^{\text {nd }}$ Edition. Sage Publication Inc, UK.

Mian, T.S. and Rizwan, M. (2013). Determinants of Customer Intention to Use Mobile Banking: an Empirical Research Based on Extended Technology Acceptance Model. Journal of Basic and Applied Scientific Research, Vol.3 (II): 20I-2I I.

Midgley, F.D. and Dowling, G.R. (I978). Innovativeness: The Concept and Its Measurement. Journal of Consumer Research, 4(4): 229-325.

Moore, G.C. and Benbasat, I. (I99I). Development of an Instrument to Measure ThePerceptions of Adopting an Information Technology Innovation.Information Systems Research, Vol. 2(3): I92-222.

Muawanah, U. (2010). Praktik Corporate Governance and Spiritual Islami di Perbankan Islamic: PendekatanMixed Method. (Unpublished Dissertation). PDIA PPSFEUB.

Olatokun, W.M. and Igbinedion, L.J. (2009). The adoption of automatic teller machines in Nigeria: An application of the Theory of Diffusion of Innovation. Issues in Informing Science and Information Technology, Vol. 6: 373-393.

Ram, S. and Sheth, J.N. (I989). Consumer resistance to innovations: the marketing problem and its solutions. Journal of Consumer Marketing, Vol. 6, No. 2: 5I4.

Raman, R. (2010). A study of consumers' adoption towards Islamic banking products and services in the state of Kedah DarulAman. (Unpublished Thesis).Universiti Utara Malaysia.

Rambocas, M. and Arjoon, S. (20I2). Using Diffusion of Innovation Theory to Model Customer Loyalty for Internet Banking: A TT Millennial perspective. International Journal of Business and Commerce, Vol.I, No.8: I-I4.

Rogers, E.M. (I97I). Communication of Innovations:A Cross-Cultural Approach $2^{\text {nd }}$ Edition. New York: Free Press. 
Rogers, E.M. and Shoemaker, F. (197I). Communications in Innovation. New York: Free Press.

Rogers, E.M. (2003). Diffusion of Innovations ( $5^{\text {th }}$ Edition). New York: Free Press.

Rugimbana, R. and Iversen, P. (1994). Perceived attributes of ATMs and their marketing implications.International Journal of Bank Marketing, Vol.I2, No.2: 30-35.

Sathye, M. (1999). Adoption of internet banking by Australian consumers: An empirical investigation. International Journal of Bank Marketing, Vol. I7(7): 324-334.

Tabachnick, B.G. and Fidell, L.S. (200I). Using Multivariate Statistics $\left(4^{\text {th }}\right.$ Edition). New York: HarperCollins.

Taylor, J.W. (1974). The role of risk in consumer behavior.Journal of Marketing, Vol. 38(2): 54-60.

Thambiah, S., Ramanathan, S. and Mazumder, M.N.H. (2012).The determinants of Islamic retail banking adoption in Malaysia.International Business and Economic Research Journal, Vol.I I, No.4: 437-442.

Yahya, M.H., Junaina M. and Abdul Razak A. H. (2012). A comparative study on the level of efficiency between Islamic and conventional banking systems in Malaysia.International Journal of Islamic and Middle Eastern Finance and Management, Vol. 5 Iss I: $48-62$.

Yahya, M.H., Junaina M., Amalina A. and Nassir, A.M. (2013). Chinks in the capitalism system- the pertinence of Islamic finance. Journal of International Business and Cultural Studies, Vol.7:I-I6.

Yusof, M.Y.R. (1999). Islamic Banking: Adoption of a Service Innovation. (Unpublished Thesis).Singapore: NanyangTechnological University (NTU). 